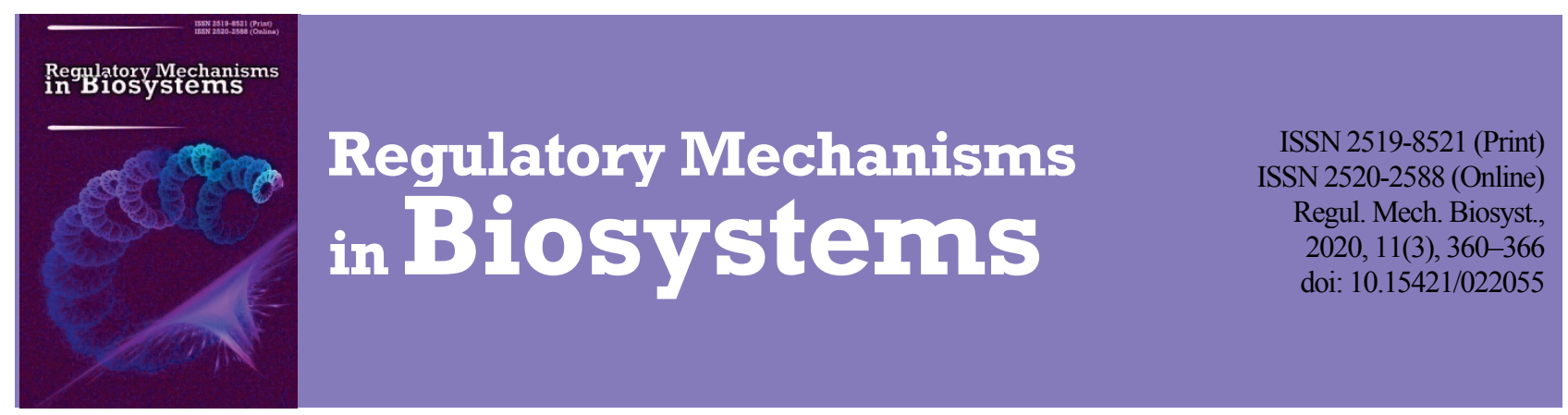

\title{
Marker changes of blood plasma proteinogram in rats with toxic hepatitis
}

\author{
V. A. Gryshchenko, V. S. Minina \\ National University of Life and Environmental Sciences of Ukraine, Kyiv, Ukraine
}

Article info

Received 24.06.2020

Received in revised form

27.07.2020

Accepted 29.07.2020

National University

of Life and Environmental

Sciences of Ukraine,

Heroyiv Oboronyst., 15

Kyiv, 03041, Ukraine.

Tel.: +38-066-910-43-43.

E-mail:

viktoriva004@ukr.net

\section{Gryshchenko, V. A., \& Minina, V.S. (2020). Marker changes of blood plasma proteinogram in rats with toxic hepatitis. Regulatory Mechanisms in Biosystems, 11(3), 360-366. doi:10.15421/022055}

In recent years, there has been a pronounced tendency to increase in the incidence of drug-induced liver damage due to the growing expansion of the pharmaceutical market, which is also observed in the case of incorrect administration of nonsteroidal anti-inflammatory drugs (NSAIDs). In this case, the violation of the functional state of the body has a negative effect on synthetic processes, which in combination with the protein system of tissues significantly affects the metabolic homeostasis of the body. Therefore, the aim of the study was to determine marker changes in the plasma protein spectrum in laboratory rats with diclofenac-induced hepatitis and the effectiveness of reparative therapy based on milk phospholipids. The drug form of toxic hepatitis in laboratory animals was induced according to the author's model by oral administration of diclofenac sodium (NSAID group) at a dose of $12.5 \mathrm{mg} / \mathrm{kg}$, once a day for 14 days. Thus, in rats with toxic hepatitis there was a probable decrease in plasma total protein content by $15.6 \%$ compared with control, indicating a violation of protein-synthesizing function of the liver. With the introduction into the body of clinically healthy and sick animals of the liposomal form of the bioadditive "FLP-MD" based on milk phospholipids, the level of total protein in blood plasma corresponded to control values. As a result of the study of the plasma protein spectrum of Wistar rats, the four most sensitive indicators, which undergo significant probable changes in absolute and relative units of measurement with the development of toxic diclofenac-induced hepatitis, are protein fractions with molecular weights of 180-190, 150-170, 60 and 54-58 kDa and four markers of the effectiveness of restoring the proteinsynthesizing function of the liver with the use of corrective therapy, in particular, bioadditives "FLP-MD" - 900, 180-190, 68-70 kDa and the value of $\mathrm{A} / \mathrm{G}$ ratio, which is important for implementation in applied veterinary medicine, especially in the diagnosis of NSAID hepatopathy, supplementing the picture of its pathogenesis at the molecular level and testing the effectiveness of newly created drugs of hepatoprotective profile.

Keywords: total protein; protein fractions; diclofenac sodium, BAA "FLP-MD", corrective effect.

\section{Introduction}

According to clinical studies, drug-induced liver damage accounts for about $10 \%$ of all adverse reactions associated with the use of chemicals (Alempijevic et al., 2017; Kullak-Ublick et al., 2017; Sanz-Villanueva et al., 2019), and this percentage is characterized by an upward trend. Thus, in Japan over a 30-year period there was an 11-fold increase in drug hepatotoxicity (Nakano et al., 2015; Cong et al., 2016). First of all, this is due to the direct participation of the liver in the biotransformation of drugs and the rapid development of the pharmaceutical market. In particular, the literature mentions a significant amount of data demonstrating the involvement of liver monooxygenases in their metabolism (Cong et al., 2016; Gutyi et al., 2019; John \& Kale, 2019). Depletion of the cytochrome P450 system involved in drug transformation can delay the elimination of toxic components of exogenous origin, cause them to accumulate in organs and tissues, or cause the formation of secondary substances, often even more toxic than the parent product. Decreased efficiency of this enzymatic system leads to increased toxicity of chemicals (Mengoli et al., 2011; Kandemir et al., 2020). This disrupts the detoxification, proteinsynthesizing function of hepatocytes, cell and subcellular membranes are damaged due to a decrease in their resistance against the background of depletion of the antioxidant system, primarily glutathione-dependent link. In addition, long-term use of chemicals can cause cumulative toxic effects on its functional state (Nakano et al., 2015). Thus, the toxic effect of chemicals is due to a decrease in their extraction by hepatocytes and is associated with both changes in enzyme activity and impaired binding to plasma proteins (Eghtesad et al., 2013). The hepatotoxic effect as a result of the use of chemicals is often manifested by a wide range of clinical and morphological manifestations of liver pathology (Aithal et al., 2011; Hu et al., 2014; Kulyaba et al., 2019). Toxic hepatitis with hepatic impairment may develop due to improper administration of nonsteroidal anti-inflammatory drugs (NSAIDs), in particular, diclofenac sodium (Rostom et al., 2005; Gryshchenko et al., 2018; Peter \& Prince, 2018). Most often, NSAID hepatopathy is manifested by severe cytolytic and cholestatic syndromes, acute liver failure at high concentrations of the drug and longterm use against the background of reduced activity of hepatocyte enzyme systems that regulate its biotransformation. Nonsteroidal anti-inflammatory drugs contribute to fluid retention and the development of liver dysfunction due to inhibition of prostaglandin synthesis.

It is known that most blood plasma proteins are synthesized in liver cells - albumins, $\alpha$-globulins, part of $\beta$-globulins, fibrinogen, components of the blood coagulation system (II, V, VII, IX, X, XI factors) (Singh et al., 2013). Plasma proteins are a labile dynamic system that is in equilibrium with such tissues and largely determines the body's metabolic homeostasis (Alberghina et al., 2011; Eghtesad et al., 2013). They are known to transport numerous exogenous and endogenous metabolites, participate in the binding of hormones, lipids, fat-soluble vitamins, etc. (Van der Vusse, 2009; Forsthuber et al., 2020). Having amphoteric properties, blood plasma proteins play an important role in maintaining the acid-base balance of the body, are blood clotting factors, antibodies (Schroeder \& Cavacini, 2010), and are used as a plastic material for their synthesis in tissues (Kragh-Hansen et al., 2002). Most pathologies in mammals are accompanied by the development of dysproteinemia, which specifically affects the quantitative characteristics of total plasma protein. It is known that total plasma protein is the total concentration of all circulating proteins and is a major component of blood plasma. According to the literature (Eghtesad 
et al., 2013), a decrease in the level of this indicator is observed in protein deficiency in the diet, endogenous intoxications (Qin et al., 2016), increased catabolism or its loss due to leaving the bloodstream with the formation of transudate exudative complexes (Dideriksen, 2013). At the same time, the content of albumin - the most numerous fraction of plasma proteins is of important diagnostic value, and its decrease indicates dysfunction of the liver, kidneys and other internal organs (Quinlan et al., 2005; Jain \& Ducatman, 2019).

Clinical and biochemical studies of liver cell integrity, excretory liver activity, cholestasis, organ function, mesenchymal and immune responses are traditionally used to assess the degree and depth of hepatocyte damage. Analysis of biochemical parameters, with a certain degree of probability, allows us to clarify the level and leading mechanism of development of liver dysfunction (Gryshchenko, 2017). In clinical practice, it is the altered laboratory parameters that are often the starting point for differential diagnosis, determination of the syndrome of liver pathology and the appointment of pathogenetic therapy. On the basis of laboratory indicators it is possible to establish the severity of the pathological process in the liver, to predict the course of the disease, as well as to determine the effectiveness of therapy. At present, the question of the peculiarities of liver proteinsynthesizing function disorders in toxic hepatitis on the background of NSAID therapy remains insufficiently studied, and it is also important to determine the effectiveness of membrane and cytoprotective action of newly developed drugs for drug cover and prevention of cytolysis syndrome.

Therefore, the aim of our work was to determine the marker changes in the plasma protein spectrum in laboratory rats with diclofenac-induced hepatitis and the effectiveness of reparative therapy based on milk phospholipids.

\section{Materials and methods}

All manipulations with rats were carried out in accordance with the requirements of the European Convention for the Protection of Vertebrate Animals Used for Experimental and Scientific Purposes (Strasbourg, 1986), the Law of Ukraine "On the Protection of Animals from Cruelty" No 3447 of 02.21.2006, which was confirmed by the conclusion of the Bioethics Commission of the National University of Life and Environmental Sciences of Ukraine, Kyiv, Ukraine.

Clinical studies were performed at the Department of Animal Biochemistry and Physiology named after Academician M. F. Gulyi, and determination of the features of qualitative and quantitative changes in the proteinogram of blood plasma were carried out on the basis of the Department of Regulation of Protein and Coenzyme Biosynthesis of the O. V. Palladin Institute of Biochemistry of the National Academy of Sciences of Ukraine.

The experiments used white laboratory rats (males) of the Wistar line with a body weight of 200-220 g, from which three experimental and control groups of ten individuals each were formed. Laboratory animals were kept on a standard vivarium diet. They had free access to food and drinking water. Prior to the experiment, the rats were quarantined with a clinical examination for two weeks. Changes in body weight and feed intake were monitored for the experimental animals. The duration of the experiment was 16 days.

The drug form of toxic hepatitis in the laboratory animals was induced by oral administration of diclofenac (NSAID group) at a dose of $12.5 \mathrm{mg} / \mathrm{kg}$, once a day for 14 days (Melnychuk \& Gryshchenko, 2016). Animals of the 1st experimental group were injected intragastrically with a probe diclofenac sodium using disposable catheters. Rats of the 2nd experimental group were intragastrically injected with a $1 \%$ solution of phospholipid-containing biologically active additive (BAA) "FLP-MD" in liposomal form at a dose of $13.5 \mathrm{mg} / \mathrm{kg}$ one hour before the use of the drug diclofenac and for the next 2 days after completion of seeding. Bioadditive "FLP-MD" is the author's development (Melnychuk et al., 2009), which includes a complex of milk phospholipids (nipples) that have a fatty acid spectrum natural for mammalian cell membranes, a mixture of unsaturated fatty acids (oleic, linoleic, linolenic), obtained with linseed oil, and antioxidants (vitamins A and E). Animals of the 3rd experimental group remained clinically healthy and received only biologically active additive
"FLP-MD" for 16 days. The control group included intact animals injected per os with an equivalent volume of distilled water.

Severe clinical symptoms of toxic hepatitis began to appear in rats of experimental groups on the seventh day of diclofenac administration and were characterized by suppression of general condition, decreased appetite, steady decrease in average body weight by $15-25 \mathrm{~g}$, dull coat, decreased skin elasticity, thin stools with unpleasant odour. Changes in the biochemical and morphological parameters of the blood characteristic of this experimental model of toxic hepatitis are described in our previous publications. (Gryshchenko, 2017).

The material for the study was heparin-stabilized blood and plasma. Blood was taken from the hearts of rats, which were previously injected under ether anesthesia. To obtain plasma, stabilized blood was centrifuged at $1500 \mathrm{rpm}$ for 20 minutes. The content of total protein in the blood plasma was determined using the biuret method using a standard set of reagents "Phyllisit-Diagnostics" (Ukraine).

The fractional composition of plasma proteins was determined by vertical electrophoresis (EF) in a polyacrylamide gel with a concentration gradient of $7-12 \%$ and the addition of $0.1 \%$ sodium dodecyl sulfate (DS$\mathrm{Na})$ by the Laemmli (1970) method. Protein zones were stained with Coomassi Brilliant BlueR-250 (Sigma-Aldrich, USA). The amount of proteins in each zone was calculated according to their graphic image obtained using the Eurochrom-2000 program and the ratio of peaks (\%) with the corresponding recalculations for total plasma protein. A mixture of standards from the firm Bioscience Amersham (Sweden) - of 15 to 250 $\mathrm{kDa}$ was used as markers.

Using the method of gel electrophoresis in the blood plasma of experimental rats, we obtained 13 protein fractions, which according to the generally accepted classification, taking into account the molecular weight (MW) of proteins, were identified as follows: 1 - more than $900 \mathrm{kDa}(\beta-$ lipoprotein and IgM zone); 2 - $340 \mathrm{kDa}$ (fibrinogen zone); 3 - 180$190 \mathrm{kDa}$ (IgE and IgD zone); $4-150-170 \mathrm{kDa}$ (IgA and IgG zone); 5 $100 \mathrm{kDa}$ (haptoglobin zone); 6 - $90 \mathrm{kDa}$ (plasminogen and post-transferrins zone); 7 - $80 \mathrm{kDa}$ (transferrin zone); $8-72 \mathrm{kDa}$ (transferrin zone); 9 68-70 kDa (albumin zone); $10-60 \mathrm{kDa}$ (antichymotrypsin and thyroxine-binding globulin zone); $11-54-58 \mathrm{kDa}$ (hemopexin and transcortin zone); $12-45 \mathrm{kDa}$ (pre-albumins zone); $13-35 \mathrm{kDa}$ (pre-albumins zone).

Analysis of the data was made using Statistica 6.0 (StatSoft Inc., USA) program. The data are presented in the tables as $\mathrm{x} \pm \mathrm{SD}(\mathrm{x} \pm$ standard deviation). Differences between the values in the control and experimental groups were determined using the Tukey test, where the differences were considered reliable at $\mathrm{P}<0.05$ (taking into account the Bonferroni correction).

\section{Results}

Qualitative and quantitative changes in the protein spectrum of blood plasma of rats with experimental diclofenac-induced hepatitis. Improper use of drugs adversely affects the functional state of the liver. Since one of its functions is protein-synthetic, the relationship between the protein spectrum of blood plasma and the degree of toxic damage to hepatocytes by drugs is obvious. At the first stage of the experiment, the content of total protein and its fractions in the blood plasma of rats with toxic hepatitis on the background of the introduction of toxic doses of diclofenac sodium were studied.

Experimentally, there was a probable decrease in the blood plasma of rats 1 st of the experimental group of the total protein content by $15.6 \%$ compared with the control. Thus, in rats with toxic hepatitis, a violation of the protein-synthesizing function of the liver was found.

At the same time, experimental modeling of toxic hepatitis in experimental rats using toxic doses of diclofenac sodium caused a probable decrease in plasma absolute content of six protein fractions, including (Table 1) proteins with molecular weights: $190-180 \mathrm{kDa}$ (IgE and IgD zone); $150-170 \mathrm{kDa}$ (IgA and IgG zone); $100 \mathrm{kDa}$ (haptoglobin zone); $90 \mathrm{kDa}$ (plasminogen and post-transferrins zone); $60 \mathrm{kDa}$ (prealbumin zone) and $54-58 \mathrm{kDa}$ (hemopexin and transcortin zone), by 54.4, 41.7, $20.3,14.9,67.6$, and $52.1 \%$, respectively, compared with the control.

In addition, studies of the relative content of plasma proteins in these animals indicate changes in their quantitative ratio (Table 1). In particular, 
the development of toxic drug-induced hepatitis in rats was manifested by an increase in the relative values of four protein fractions, namely with molecular weights: more than $900 \mathrm{kDa}$ ( $\beta$-lipoprotein and IgM zone); $72 \mathrm{kDa}$ (transferrin zone); $68-70 \mathrm{kDa}$ (albumin zone) and 45 (pre-albumins zone), respectively, 1.1,1.3, 1.1 and 1.6 times compared to control. At the same time, in the blood plasma of these animals there was a decrease in the relative content of a similar number of protein fractions with molecular weights: $180-190 \mathrm{kDa}$ (IgE and $\operatorname{IgD}$ zone); $150-170 \mathrm{kDa}$ (IgA and $\operatorname{IgG}$ zone); $60 \mathrm{kDa}$ (antichymotrypsin and thyroxine-binding globulin zone) and 54-58 kDa (hemopexin and transcortin zone), 1.9, 1.5, 2.6 and 1.8 times compared to control.

\section{Table 1}

Total protein and its fractions in the blood plasma of rats with diclofenac-induced hepatitis $(\mathrm{x} \pm \mathrm{SD}, \mathrm{n}=10)$

\begin{tabular}{|c|c|c|c|c|}
\hline Protein zone & $\begin{array}{l}\text { Unit of } \\
\text { measure- } \\
\text { ment }\end{array}$ & $\begin{array}{l}\text { Clinically } \\
\text { healthy rats } \\
\text { (control) }\end{array}$ & $\begin{array}{l}\text { Rats suffering from } \\
\text { toxic hepatitis } \\
\text { (self-rehabilitation) }\end{array}$ & $\begin{array}{l}\text { MW } \\
\text { protein, } \\
\mathrm{kDa}\end{array}$ \\
\hline Total protein & $\mathrm{g} / \mathrm{L}$ & $71.95 \pm 3.01^{\mathrm{a}}$ & $60.71 \pm 2.43^{b}$ & - \\
\hline \multirow{2}{*}{$\beta$-Lipoproteins and IgM } & $\mathrm{g} / \mathrm{L}$ & $1.14 \pm 0.04^{\mathrm{a}}$ & $1.10 \pm 0.04^{\mathrm{a}}$ & \multirow{2}{*}{900} \\
\hline & $\%$ & $1.59 \pm 0.04^{\mathrm{a}}$ & $1.81 \pm 0.01^{\mathrm{b}}$ & \\
\hline \multirow{2}{*}{ Fibrinogen } & $\mathrm{g} / \mathrm{L}$ & $2.68 \pm 0.18^{\mathrm{a}}$ & $2.16 \pm 0.23^{\mathrm{a}}$ & \multirow{2}{*}{340} \\
\hline & $\%$ & $3.72 \pm 0.24^{\mathrm{a}}$ & $3.54 \pm 0.32^{\mathrm{a}}$ & \\
\hline \multirow{2}{*}{$\mathrm{IgE}$ and $\mathrm{IgD}$} & $\mathrm{g} / \mathrm{L}$ & $3.90 \pm 0.14^{\mathrm{a}}$ & $1.78 \pm 0.06^{\mathrm{b}}$ & \multirow{2}{*}{$180-190$} \\
\hline & $\%$ & $5.43 \pm 0.18^{\mathrm{a}}$ & $2.93 \pm 0.03^{b}$ & \\
\hline \multirow{2}{*}{$\operatorname{IgA}$ and $\operatorname{IgG}$} & $\mathrm{g} / \mathrm{L}$ & $3.67 \pm 0.19^{\mathrm{a}}$ & $2.14 \pm 0.13^{\mathrm{b}}$ & \multirow{2}{*}{$150-170$} \\
\hline & $\%$ & $5.11 \pm 0.88^{\mathrm{a}}$ & $3.53 \pm 0.31^{\mathrm{b}}$ & \\
\hline \multirow{2}{*}{ Haptoglobin } & $\mathrm{g} / \mathrm{L}$ & $2.96 \pm 0.07^{\mathrm{a}}$ & $2.36 \pm 0.04^{b}$ & \multirow{2}{*}{100} \\
\hline & $\%$ & $4.12 \pm 0.12^{\mathrm{a}}$ & $3.89 \pm 0.17^{\mathrm{a}}$ & \\
\hline \multirow{2}{*}{$\begin{array}{l}\text { Plasminogen and } \\
\text { post-transferrins }\end{array}$} & $\mathrm{g} / \mathrm{L}$ & $6.72 \pm 0.23^{\mathrm{a}}$ & $5.72 \pm 0.24^{b}$ & \multirow{2}{*}{90} \\
\hline & $\%$ & $9.32 \pm 1.04^{\mathrm{a}}$ & $9.45 \pm 0.53^{\mathrm{a}}$ & \\
\hline \multirow{2}{*}{ Transferrin } & $\mathrm{g} / \mathrm{L}$ & $4.89 \pm 0.17^{\mathrm{a}}$ & $3.60 \pm 0.20^{\mathrm{a}}$ & \multirow{2}{*}{80} \\
\hline & $\%$ & $6.79 \pm 0.42^{\mathrm{a}}$ & $5.93 \pm 0.34^{\mathrm{a}}$ & \\
\hline \multirow{2}{*}{ Transferrin } & $\mathrm{g} / \mathrm{L}$ & $11.23 \pm 0.39^{\mathrm{a}}$ & $11.89 \pm 0.34^{\mathrm{a}}$ & \multirow{2}{*}{72} \\
\hline & $\%$ & $15.60 \pm 0.52^{\mathrm{a}}$ & $19.62 \pm 0.38^{\mathrm{b}}$ & \\
\hline \multirow{2}{*}{ Albumin } & $\mathrm{g} / \mathrm{L}$ & $25.68 \pm 1.10^{\mathrm{a}}$ & $23.43 \pm 1.04^{\mathrm{a}}$ & \multirow{2}{*}{$68-70$} \\
\hline & $\%$ & $35.73 \pm 0.63^{\mathrm{a}}$ & $38.57 \pm 0.71^{\mathrm{b}}$ & \\
\hline \multirow{4}{*}{$\begin{array}{l}\text { Antichymotrypsin and thy- } \\
\text { roxine-binding globulin } \\
\text { Hemopexin and } \\
\text { transcortin }\end{array}$} & $\mathrm{g} / \mathrm{L}$ & $3.89 \pm 0.70^{\mathrm{a}}$ & $1.26 \pm 0.19^{\mathrm{b}}$ & \multirow{2}{*}{60} \\
\hline & $\%$ & $5.40 \pm 0.21^{\mathrm{a}}$ & $2.05 \pm 0.17^{b}$ & \\
\hline & $\mathrm{g} / \mathrm{L}$ & $1.42 \pm 0.12^{\mathrm{a}}$ & $0.68 \pm 0.14^{\mathrm{b}}$ & \\
\hline & $\%$ & $1.97 \pm 0.27^{\mathrm{a}}$ & $1.12 \pm 0.20^{b}$ & $54-58$ \\
\hline \multirow{2}{*}{ Pre-albumins } & $\mathrm{g} / \mathrm{L}$ & $2.75 \pm 0.36^{\mathrm{a}}$ & $3.61 \pm 0.30^{\mathrm{a}}$ & \multirow{2}{*}{45} \\
\hline & $\%$ & $3.82 \pm 0.34^{\mathrm{a}}$ & $5.92 \pm 0.18^{b}$ & \\
\hline \multirow{2}{*}{ Pre-albumins } & $\mathrm{g} / \mathrm{L}$ & $1.01 \pm 0.59^{\mathrm{a}}$ & $0.99 \pm 0.02^{\mathrm{a}}$ & \multirow{2}{*}{35} \\
\hline & $\%$ & $1.40 \pm 0.29^{\mathrm{a}}$ & $1.64 \pm 0.02^{\mathrm{a}}$ & \\
\hline A/G ratio & - & $0.56 \pm 0.04^{\mathrm{a}}$ & $0.63 \pm 0.03^{\mathrm{a}}$ & - \\
\hline
\end{tabular}

Note: different letters indicate values which reliably differed from one another within one line of the Table according to the results of comparison using Tukey test with Bonferroni correction.

An important diagnostic test for the state of protein metabolism in mammals is the albumin-globulin (A/G) ratio. In the case of experimental NSAID hepatopathy in the blood plasma of experimental rats there is a simultaneous decrease in the absolute content of both the albumin fraction and the total amount of proteins of globulin heterogeneous fractions, so the value of the $\mathrm{A} / \mathrm{G}$ ratio remains unchanged. These trends indicate not only changes in the protein-synthesizing function of the liver, but also other organs, primarily immunocompetent. The absence of probable changes in the studied indicator is a pronounced compensatory reaction of the body in response to the development of toxic hepatitis in order to maintain metabolic homeostasis (Table 1).

Corrective efficacy of milk phospholipids in experimental diclofenacinduced hepatitis. In the case of the use of phospholipid-containing bioadditive "FLP-MD" in sick animals, the protein-synthesizing function of hepatocytes was improved, which is an important component of its reparative effect on the damaged liver. In particular, both when the phospholipid-containing bioadditive (Table 2) was administered to clinically healthy animals and as a result of its administration to rats in a state of experimental toxic hepatitis, the correspondence of total protein content with the value of this indicator in the control was discovered.

Some quantitative changes are observed for a number of protein fractions. Thus, in clinically healthy animals administered BAA "FLP-MD", there was an absolute increase in the content of four protein fractions with molecular weights: $900 \mathrm{kDa}$ ( $\beta$-lipoprotein and IgM zone) by 31.6\%; $100 \mathrm{kDa}$ (haptoglobin zone) by $39.2 \%$; $68-70 \mathrm{kDa}$ (albumin zone) by $15.3 \%$ and $35 \mathrm{kDa}$ (prealbumin zone) by $96.0 \%$ and reduction of the level of two protein fractions with molecular weights: $80 \mathrm{kDa}$ (transferrin zone) by $48.3 \% ; 60 \mathrm{kDa}$ (antichymotrypsin and thyroxine-binding globulin zone) by $70.5 \%$ compared to the control (Table 2 ). In turn, in the blood plasma of animals with toxic hepatitis and who were orally administered BAA "FLP-MD", there was an increase in the concentration of proteins with molecular weights: $900 \mathrm{kDa}$ ( $\beta$-lipoprotein and IgM zone) by $25.4 \%$; $180-190 \mathrm{kDa}$ (IgE and IgD zone) at $25.9 \% ; 72 \mathrm{kDa}$ (transferrin zone) by $13.2 \% ; 68-70 \mathrm{kDa}$ (albumin zone) by $20.3 \%$ and a decrease in the level of proteins with a molecular weight of $100 \mathrm{kDa}$ (haptoglobin zone) by $37.5 \% ; 90 \mathrm{kDa}$ (plasminogen and post-transferrins zone) by $17.6 \%$; $80 \mathrm{kDa}$ (transferrin zone) by $57.7 \%$; $60 \mathrm{kDa}$ (antichymotrypsin and thyroxine-binding globulin zone) by $82.8 \%$ and $54-58 \mathrm{kDa}$ (hemopexin and transcortin zone) by $36.6 \%$ compared to controls (Table 2 ).

\section{Table 2}

Total protein and its fractions in the blood plasma of rats with diclofenacinduced hepatitis and the use of reparative therapy $(x \pm S D, n=10)$

\begin{tabular}{|c|c|c|c|c|c|}
\hline Protein zone & $\begin{array}{l}\text { Unit of } \\
\text { measur } \\
\text { ement }\end{array}$ & $\begin{array}{c}\text { Clinically } \\
\text { healthy rats } \\
\text { (control) }\end{array}$ & $\begin{array}{c}\text { Clinically } \\
\text { healthy rats } \\
\text { injected with } \\
\text { BAA "FLP- } \\
\text { MD"' }\end{array}$ & $\begin{array}{c}\text { Rats suffering } \\
\text { from toxic } \\
\text { hepatitis injected } \\
\text { with BAA } \\
\text { "FLP-MD" }\end{array}$ & $\begin{array}{c}\text { MW } \\
\text { protein, } \\
\mathrm{kDa}\end{array}$ \\
\hline Total protein & $\mathrm{g} / \mathrm{L}$ & $71.95 \pm$ & $72.46 \pm 2.03^{\mathrm{a}}$ & $72.30 \pm 3.39^{\mathrm{a}}$ & - \\
\hline \multirow{2}{*}{$\begin{array}{l}\beta \text {-Lipoproteins } \\
\text { and IgM }\end{array}$} & $\mathrm{g} / \mathrm{L}$ & $1.14 \pm 0.04^{\mathrm{a}}$ & $1.50 \pm 0.10^{\mathrm{b}}$ & $1.43 \pm 0.08^{b}$ & \multirow{2}{*}{900} \\
\hline & $\%$ & $1.59 \pm 0.04^{\mathrm{a}}$ & $2.07 \pm 0.18^{\mathrm{b}}$ & $1.98 \pm 0.14^{\mathrm{b}}$ & \\
\hline \multirow{2}{*}{ Fibrinogen } & $\mathrm{g} / \mathrm{L}$ & $2.68 \pm 0.18^{\mathrm{a}}$ & $2.72 \pm 0.09^{\mathrm{a}}$ & $3.12 \pm 0.16^{\mathrm{a}}$ & \multirow{2}{*}{340} \\
\hline & $\%$ & $3.72 \pm 0.24^{\mathrm{a}}$ & $3.76 \pm 0.05^{\mathrm{a}}$ & $4.32 \pm 0.29^{\mathrm{a}}$ & \\
\hline \multirow{2}{*}{$\operatorname{IgE}$ and $\operatorname{IgD}$} & $\mathrm{g} / \mathrm{L}$ & $3.90 \pm 0.21^{\mathrm{a}}$ & $3.60 \pm 0.11^{\mathrm{a}}$ & $4.91 \pm 0.15^{\mathrm{b}}$ & \multirow{2}{*}{$180-190$} \\
\hline & $\%$ & $5.43 \pm 0.18^{\mathrm{a}}$ & $4.98 \pm 0.61^{\mathrm{a}}$ & $6.81 \pm($ & \\
\hline \multirow{2}{*}{$\operatorname{IgA}$ and $\operatorname{IgG}$} & $\mathrm{g} / \mathrm{L}$ & $3.67 \pm 0.28^{\mathrm{a}}$ & $3.91 \pm 0.25^{\mathrm{a}}$ & $3.41 \pm$ & \multirow{2}{*}{$150-170$} \\
\hline & $\%$ & $5.11 \pm($ & $5.37 \pm 0.34^{\mathrm{a}}$ & $4.70 \pm 0.51^{\mathrm{a}}$ & \\
\hline \multirow{2}{*}{ Haptoglobin } & $\mathrm{g} / \mathrm{L}$ & $2.96 \pm 0.27^{\mathrm{a}}$ & $4.12 \pm 0.29^{b}$ & $1.85 \pm 0.22^{\mathrm{c}}$ & \multirow{2}{*}{100} \\
\hline & $\%$ & $4.12 \pm 0.32^{\mathrm{a}}$ & $5.65 \pm 0.30^{b}$ & $2.56 \pm 0.23^{c}$ & \\
\hline \multirow{2}{*}{$\begin{array}{l}\text { Plasminogen and } \\
\text { post-transferrins }\end{array}$} & $\mathrm{g} / \mathrm{L}$ & $6.72 \pm 0.13^{\mathrm{a}}$ & $6.51 \pm 0.22^{\mathrm{a}}$ & $5.54 \pm 0.23^{\mathrm{b}}$ & \multirow{2}{*}{90} \\
\hline & $\%$ & $9.32 \pm 0.84^{\mathrm{a}}$ & $9.01 \pm 0.81^{\mathrm{a}}$ & $7.64 \pm 0.90^{\mathrm{a}}$ & \\
\hline \multirow{2}{*}{ Transferrin } & $\mathrm{g} / \mathrm{L}$ & $4.89 \pm 0.17^{\mathrm{a}}$ & $2.53 \pm 0.31^{\mathrm{b}}$ & $2.07 \pm 0.21^{\mathrm{b}}$ & \multirow{2}{*}{80} \\
\hline & $\%$ & $6.79 \pm 0.42^{\mathrm{a}}$ & $3.50 \pm 0.14^{\mathrm{b}}$ & $2.86 \pm 0.21^{\mathrm{c}}$ & \\
\hline \multirow{2}{*}{ Transferrin } & $\mathrm{g} / \mathrm{L}$ & $11.23 \pm 0.19^{\mathrm{a}}$ & $10.63 \pm 0.22^{\mathrm{a}}$ & $12.71 \pm 0.27^{b}$ & \multirow{2}{*}{72} \\
\hline & $\%$ & $15.60 \pm 0.72^{\mathrm{a}}$ & $14.72 \pm 0.51^{\mathrm{a} b \mathrm{~b}}$ & $17.51 \pm 0.58^{\mathrm{a}}$ & \\
\hline \multirow{2}{*}{ Albumin } & $\mathrm{g} / \mathrm{L}$ & $25.68 \pm 0.20^{\mathrm{a}}$ & $29.61 \pm 0.61^{b}$ & $30.90 \pm 0.24^{b}$ & \multirow{2}{*}{$68-70$} \\
\hline & $\%$ & $35.73 \pm 0.65^{\mathrm{a}}$ & $40.86 \pm 0.48^{\mathrm{b}}$ & $42.82 \pm 0.62^{c}$ & \\
\hline \multirow{2}{*}{$\begin{array}{l}\text { Antichymotrypsi } \\
\mathrm{n} \text { and thyroxine- } \\
\text { binding globulin }\end{array}$} & $\mathrm{g} / \mathrm{L}$ & $3.89 \pm 0.50^{\mathrm{a}}$ & $1.13 \pm 0.28^{b}$ & $0.67 \pm 0.36^{\mathrm{b}}$ & \multirow[b]{2}{*}{60} \\
\hline & $\%$ & $5.40 \pm 0.61^{\mathrm{a}}$ & $1.55 \pm 0.34^{\mathrm{b}}$ & $0.94 \pm 0.12^{\mathrm{b}}$ & \\
\hline \multirow{2}{*}{$\begin{array}{l}\text { Hemopexin and } \\
\text { transcortin }\end{array}$} & $\mathrm{g} / \mathrm{L}$ & $1.42 \pm 0.22^{\mathrm{a}}$ & $1.03 \pm 0.13^{\mathrm{ab}}$ & $0.90 \pm 0.08^{b}$ & \multirow{2}{*}{$54-58$} \\
\hline & $\%$ & & $1.43 \pm 0.29^{\mathrm{ab}}$ & $1.25 \pm 0.11^{\mathrm{b}}$ & \\
\hline \multirow{2}{*}{ Pre-albumins } & $\mathrm{g} / \mathrm{L}$ & $2.75 \pm 0.26^{\mathrm{a}}$ & $3.19 \pm 0.29^{\mathrm{a}}$ & $3.18 \pm 0.19^{\mathrm{a}}$ & \multirow{2}{*}{45} \\
\hline & $\%$ & $3.82 \pm 0.24^{\mathrm{a}}$ & $4.40 \pm 0.27^{\mathrm{a}}$ & $4.39 \pm 0.26^{\mathrm{a}}$ & \\
\hline \multirow{2}{*}{ Pre-albumins } & $\mathrm{g} / \mathrm{L}$ & $1.01 \pm 0.19^{\mathrm{a}}$ & $1.98 \pm 0.14^{\mathrm{b}}$ & $1.61 \pm 0.29^{\mathrm{a}}$ & \multirow{2}{*}{35} \\
\hline & $\%$ & $1.40 \pm 0.23^{\mathrm{a}}$ & $2.70 \pm 0.21^{\mathrm{b}}$ & $2.22 \pm 0.20^{\mathrm{a}}$ & \\
\hline $\mathrm{A} / \mathrm{G}$ ratio & - & $0.56 \pm 0.04^{\mathrm{a}}$ & $0.71 \pm 0.05^{\mathrm{b}}$ & $0.75 \pm 0.05^{\mathrm{b}}$ & - \\
\hline
\end{tabular}

Note: different letters indicate values which reliably differed one from another within one line of the Table according to the results of comparison using Tukey test with Bonferroni correction.

At the same time, the administration to clinically healthy rats of BAA "FLP-MD", which contains milk phospholipids natural for the body of mammals, led to a probable increase in blood plasma by $26.6 \%$ of the $\mathrm{A} / \mathrm{G}$ ratio. A similar pattern was observed in the group of sick animals which also received this supplement. At the same time, the shifts in the $\mathrm{A} / \mathrm{G}$ ratio deviate even more from its value in the control and make a difference of $33.9 \%$. The established patterns are primarily related to the stimulating effect of bioadditive components on the protein-synthesizing function of hepatocytes, which primarily follows from the probable increase in blood plasma of rats of the relevant experimental groups of the most massive homogeneous protein fraction - albumin, which is the site of synthesis. In this case, the total number of globulin fractions in the blood plasma of these animals tends to decrease. In addition, there is a specific picture of the quantitative redistribution of proteins by relative content in blood plasma (Table 2). Thus, the introduction into the body of 
clinically healthy rats of BAA "FLP-MD" contributed to an increase in the relative amount of proteins with molecular weights: more than $900 \mathrm{kDa}$ ( $\beta$-lipoprotein and IgM zone) by 1.3 times, $100 \mathrm{kDa}$ (haptoglobin zone) 1.4 times, $68-70 \mathrm{kDa}$ (albumin zone) by 1.1 times and $35 \mathrm{kDa}$ (pre-albumins zone) by 1.9 times and reduction of protein content with molecular weights of $80 \mathrm{kDa}$ (transferrin zone) by 1.9 times; $60 \mathrm{kDa}$ (antichymotrypsin and thyroxine-binding globulin zone) by 3.5 times compared to the control. At the same time, the administration of BAA "FLP-MD" to sick animals was marked by an increase in the relative content of proteins with molecular weights: $900 \mathrm{kDa}$ ( $\beta$-lipoprotein and IgM zone) by 1.3 times, 180-190 kDa (IgE and IgD zone) 1.3 times, $68-70 \mathrm{kDa}$ (albumin zone) by 1.2 times and reduction of protein level with molecular weights: $100 \mathrm{kDa}$ (haptoglobin zone) by 1.6 times, $80 \mathrm{kDa}$ (transferrin zone) 2.4 times, $60 \mathrm{kDa}$ (antichymotrypsin and thyroxine-binding globulin zone) 5.7-fold and 54-58 kDa (hemopexin and transcortin zone) 1.6-fold compared to controls.

As a result of comparison of the absolute content of protein fractions in the blood plasma of sick rats injected with BAA "FLP-MD" with clinically healthy animals given a similar bioadditive, there was an increase in the concentration of protein fractions with molecular weights: 180 $190 \mathrm{kDa}$ (IgE and $\operatorname{IgD}$ zone) by $36.4 \%$ and $72 \mathrm{kDa}$ (transferrin zone) by $19.6 \%$ and a decrease in the level of $100 \mathrm{kDa}$ (haptoglobin zone) by $55.1 \%$ and $90 \mathrm{kDa}$ (plasminogen and post-transferrins zone) by $14.9 \%$ (Table 2). At the same time, there are certain patterns of changes in the relative content of protein fractions in the blood plasma of sick rats of these groups in a comparative aspect (Table 2). In particular, the relative number of protein fractions with molecular weights increased: 180 $190 \mathrm{kDa}$ (IgE and $\mathrm{IgD}$ zone) by 1.4 times, $72 \mathrm{kDa}$ (transferrin zone) 1.2 times and $68-70 \mathrm{kDa}$ (albumin zone) 1.1 times and there was a reduction in the following protein fractions with molecular weights: $100 \mathrm{kDa}$ (haptoglobin zone) 2.2 times and $80 \mathrm{kDa}$ (zone transferrin) 1.2 times.

Therefore, in the case of animals with toxic hepatitis, the phospholipid-containing bioadditive "FLP-MD" improved the protein-synthesizing function of hepatocytes, which is an important component of its reparative effect on the damaged liver. A number of features of the absolute and relative quantitative characteristics of the protein spectrum of blood plasma in sick animals were identified and the most pronounced of them were identified, which has valuable diagnostic and prognostic value in NSAID hepatopathy.

\section{Discussion}

Currently, numerous studies by scientists indicate the presence of impaired metabolic activity of the liver due to toxic effects on the body of exogenous and endogenous factors of various origins (Kullak-Ublick et al., 2017; Peter \& Prince, 2018; Forsthuber, 2020). Increasingly, information appears in the literature that indicates a growing role of drug factors in the development of relevant nosological forms of hepatopathies (Aithal et al., 2011; Alempijevic \& Milosavljevic, 2017; Sanz-Villanueva et al., 2019). Among the drugs that are particularly toxic to the liver are nonsteroidal anti-inflammatory drugs, in particular, diclofenac sodium (Rostom et al., 2005; Gryshchenko, 2017; Thakkar et al., 2018). Therefore, the material of our publication highlights the established experimental patterns of quantitative changes in the proteinogram of blood plasma of laboratory rats in diclofenac-induced hepatitis.

As a result of the analysis of protein composition of blood plasma of rats with experimental diclofenac-induced hepatitis and on the background of the introduction of milk phospholipids in the form of liposomal form BAA "FLP-MD" we identified a number of important diagnostic points in the pathogenesis of NSAIDs and hepatitis. This complements the already known facts (Calitz et al., 2018; Markley \& Wencewicz, 2018; Schueller et al., 2018).

Thus, in rats with toxic hepatitis, there was a probable decrease in plasma total protein content by $15.6 \%$ compared with controls, indicating a violation of protein-synthesizing function of the liver. For the introduction to clinically healthy animals and patients with toxic hepatitis of bioadditives "FLP-MD" there is compliance with control values of this indicator, which positively characterizes the protein-synthesizing function of hepatocytes, which is an important component of the reparative effect of milk phospholipids, especially on the damaged liver and which is partly described in our previous work (Melnychuk et al., 2009; Gryshchenko, 2019).

Experimental reproduction of toxic hepatitis in rats according to the author's model using toxic doses of diclofenac sodium caused a probable decrease in plasma absolute content of six protein fractions (Fig. 1), in particular: 180-190 kDa (IgE and IgD zone); $150-170 \mathrm{kDa}$ (IgA and IgG zone); $100 \mathrm{kDa}$ (haptoglobin zone); $90 \mathrm{kDa}$ (plasminogen and post-transferrins zone); $60 \mathrm{kDa}$ (pre-albumin zone) and $54-58 \mathrm{kDa}$ (hemopexin and transcortin zone), respectively by $54.4 \%, 41.7,20.3,14.9,67.6$ and $52.1 \%$ compared to the control, which indicates a violation of metabolic, immunoregulatory, protective, transport, antitoxic functions of the liver.

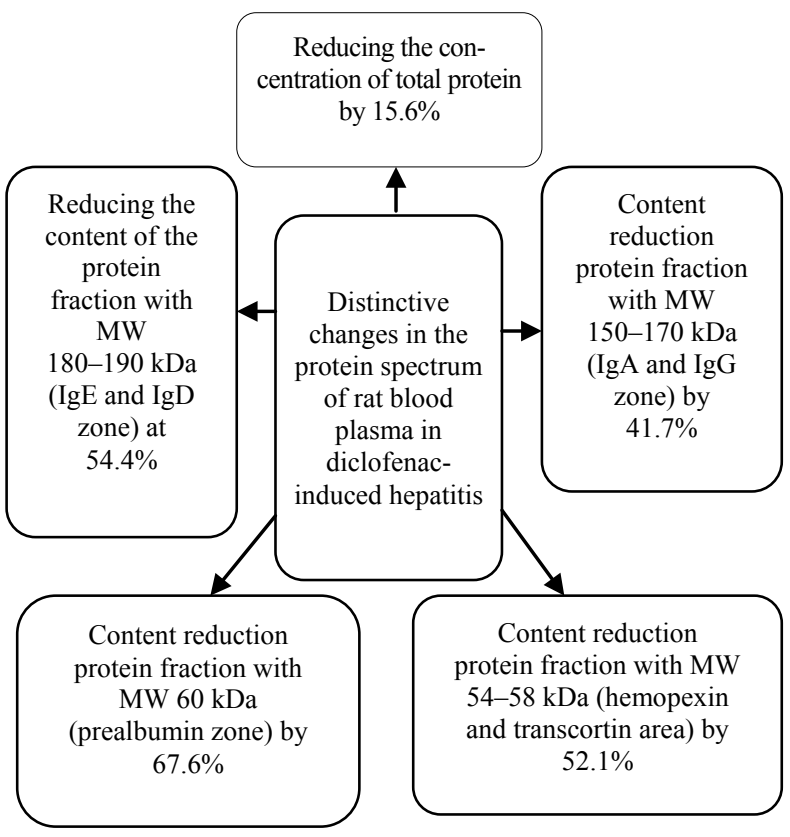

Fig. 1. Features of the protein spectrum of blood plasma of rats with diclofenac-induced hepatitis

At the same time, among these six protein fractions, only four show similar trends in the relative content in the blood plasma of rats under conditions of self-rehabilitation and are characterized by the most pronounced deviations from control values, namely: $180-190 \mathrm{kDa}$ (IgE and IgD zone) 1.9 times; $150-170 \mathrm{kDa}$ (IgA and IgG zone) 1.5 times; $60 \mathrm{kDa}$ (pre-albumin zone) 2.6 times and $54-58 \mathrm{kDa}$ (hemopexin and transcortin zone) 1.8 times. Therefore, summarizing the absolute and relative quantitative changes of these protein fractions in the blood plasma of rats with toxic hepatitis, the most sensitive indicators include those corresponding to molecular weights of 180-190, 150-170, 60 and $54-58 \mathrm{kDa}$.

The development of hypoproteinemia on the background of a significant decrease in the plasma of a number of protein fractions is a reflection of the suppression of the synthetic function of the liver as a result of its toxic damage by diclofenac sodium. A significant decrease in the plasma of almost all classes of immunoglobulins (G, A, E, D) is noteworthy, which may indicate the development of humoral immune deficiency in sick animals (Schroeder \& Cavacini, 2010; Qin et al., 2016; Calitz et al., 2018). The combination of chronic toxic liver damage of drug etiology with the development of the inflammatory process leads to a sharp decrease in the content of pre-albumins in blood plasma, as noted in their work and that of other authors (Alberghina et al., 2011; Eghtesad et al., 2011). Deficient levels of pre-albumins in the blood plasma of sick rats are a marker of impaired protein-synthesizing function of hepatocytes. In general, pre-albumins perform a transport function, binding and transporting thyroxine and retinol. As a rule, the described changes in prealbumins in the blood plasma of mammals are observed simultaneously with a significant decrease in the content of hemopexin and transcortin (Alberghina et al., 2011), which occurs in our case. Hemopexin - binds heme, which prevents it from being lost through the kidneys and stores iron for the body, and transcortin is a transport form of corticosteroids. The decrease in their content in the blood plasma of sick animals is direct- 
ly related to the development of an inflammatory process in the liver parenchyma due to inhibition of their synthesis by cytokines.

The use of BAA "FLP-MD" in sick rats on the background of restoring the total protein content is marked by an absolute increase in plasma concentrations of proteins with molecular weights: $900 \mathrm{kDa}$ ( $\beta$-lipoprotein and IgM zone) by $25.4 \%, 180-190 \mathrm{kDa}$ (IgE and $\mathrm{IgD}$ zone) at $25.9 \%$, $72 \mathrm{kDa}$ (transferrin zone) by $13.2 \%, 68-70 \mathrm{kDa}$ (albumin zone) by $20.3 \%$ and decrease $-100 \mathrm{kDa}$ (haptoglobin zone) by $37.5 \%, 90 \mathrm{kDa}$ (plasminogen and post-transferrins zone) by $17.6 \%, 80 \mathrm{kDa}$ (transferrin zone) by $57.7 \% ; 60 \mathrm{kDa}$ (antichymotrypsin and thyroxine-binding globulin zone) by $82.8 \%$ and $54-58 \mathrm{kDa}$ (hemopexin and transcortin zone) by $36.6 \%$ compared to the control, which proves the corrective effect of the phospholipid-containing bioadditive (Fig. 2). At the same time, the value of the A/G ratio also increases by $33.9 \%$ compared to the control (intact animals).

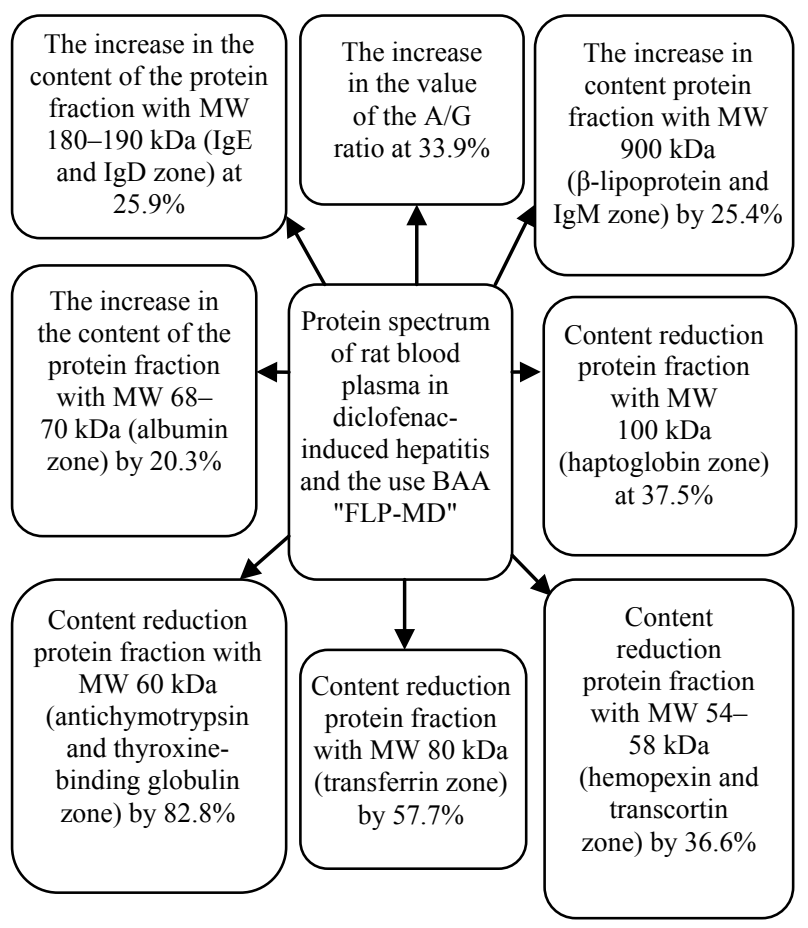

Fig. 2. Specific effect of corrective therapy in the form of BAA "FLP-MD" on the protein spectrum of blood plasma of rats with diclofenac-induced hepatitis

In addition, it is worth noting the quantitative changes in protein fractions, which are characterized by similar trends in changes in their relative content in the blood plasma of sick rats. Thus, the increase in the relative amount in the blood plasma of sick rats relates to three protein fractions with molecular weights: $900 \mathrm{kDa}$ ( $\beta$-lipoprotein zone and $\mathrm{IgM}$ ) by 1.3 times; $180-190 \mathrm{kDa}$ (IgE and IgD zone) 1.3 times and $68-70 \mathrm{kDa}$ (albumin zone) 1.2 times, and the decrease in the relative level is characteristic of four protein fractions with molecular weights: $100 \mathrm{kDa}$ (haptoglobin zone) in 1.6 times, $80 \mathrm{kDa}$ (transferrin zone) by 2.4 times, $60 \mathrm{kDa}$ (antichymotrypsin and thyroxine-binding globulin zone) 5.7 times and $54-58 \mathrm{kDa}$ (hemopexin and transcortin zone) 1.6 times. Thus, taking into account the absolute and relative changes in the quantitative characteristics of the indicator, to determine the reparative efficiency of newly created drugs of hepatoprotective profile, to marker indicators one should include the following protein fractions: $900 \mathrm{kDa}$ ( $\beta$-lipoprotein and IgM zone); 180-190 kDa (IgE and IgD zone), 68-70 kDa (albumin zone) and the value of $A / G$ ratio - are marked by an increase in their content in the blood plasma of sick animals (Fig. 2).

Among the changes in the proteinogram of blood plasma in sick rats who received corrective therapy in the form of BAA "FLP-MD" on the background of the restoration of total protein content, the development of hyperalbuminemia first of all attracts attention. In fact, this leads to an increase in the value of the $\mathrm{A} / \mathrm{G}$ ratio. As is known from the literature (Kragh-Hansen et al., 2002; Quinlan et al., 2005; Van der Vusse, 2009;
Forsthuber et al., 2020), albumin is the most massive protein fraction of the liquid part of the blood, which by $80 \%$ determines its colloidal osmotic pressure, involved in providing a buffer capacity, acts as a reserve of free amino acids in the body and so on. It should be noted that the synthesis of this protein occurs only in hepatocytes and directly depends on the intake of amino acids with food, in particular tryptophan, as well as the presence of ATP, glutathione transferase (Singh et al., 2013) and $\mathrm{Mg}^{2+}$ ions (Jain \& Ducatman, 2019). Probably, the occurrence of hyperalbuminemia in our case is associated with the restoration of the synthetic function of hepatocytes (Quinlan et al., 2005). In addition, albumin is involved in the regulation of the pool of free fatty acids (FFA) in blood plasma, which is a reflection of its transport function (Van der Vusse, 2009). Under physiological conditions, the albumin molecule can bind and transport 2-4 FFA, which reduces the concentration of active free fatty acids in blood plasma. Therefore, it can be assumed that the increase in the amount of albumin in the blood plasma of experimental rats under the conditions of experimental hepatopathology and administration of bioadditives may be one of the factors preventing the development of fatty infiltration of the liver, which prevents unwanted complications. At the same time, in these animals the content of a number of immunoglobulins increases: classes M, D and E, which indicates the mobilization of the body's protective factors, which is primarily associated with toxic liver damage. Finally, $\beta$-lipoproteins, which are a transport form of lipids, are known to be formed in the liver (Mengoli et al., 2011), and therefore an increase in their number may indicate the restoration of metabolic function of the body, including cholesterol and phospholipid metabolism. In particular, the latter are the main active ingredient of the bioadditive "FLP-MD", which in turn explains the high content of $\beta$-lipoproteins in the blood plasma of experimental rats. In turn, the decrease in plasma of animals of this group of individual protein fractions, directly, haptoglobin, antichymotrypsin, thyroxine-binding globulin, transferrin, hemopexin and transcortin, may indicate their intense involvement in the regenerative processes, due to the known transport function (Qin et al., 2016).

Administration of BAA "FLP-MD" to clinically healthy animals was accompanied by an absolute increase in the content of protein fractions with molecular weights: $900 \mathrm{kDa}$ ( $\beta$-lipoprotein and IgM zone) by $31.6 \%$, $100 \mathrm{kDa}$ (haptoglobin zone) by $39.2 \%, 60-70 \mathrm{kDa}$ (albumin zone) by $15.3 \%$ and $35 \mathrm{kDa}$ (pre-albumin zone) by $96.0 \%$ and a decrease of $80 \mathrm{kDa}$ (transferrin zone) by $48.3 \%, 60 \mathrm{kDa}$ (antichymotrypsin and thyroxine-binding globulin zone) by $70.5 \%$ compared to the control, which indicates an increase in the regulatory role of the liver in protein metabolism under the action of bioadditives (Fig. 3).

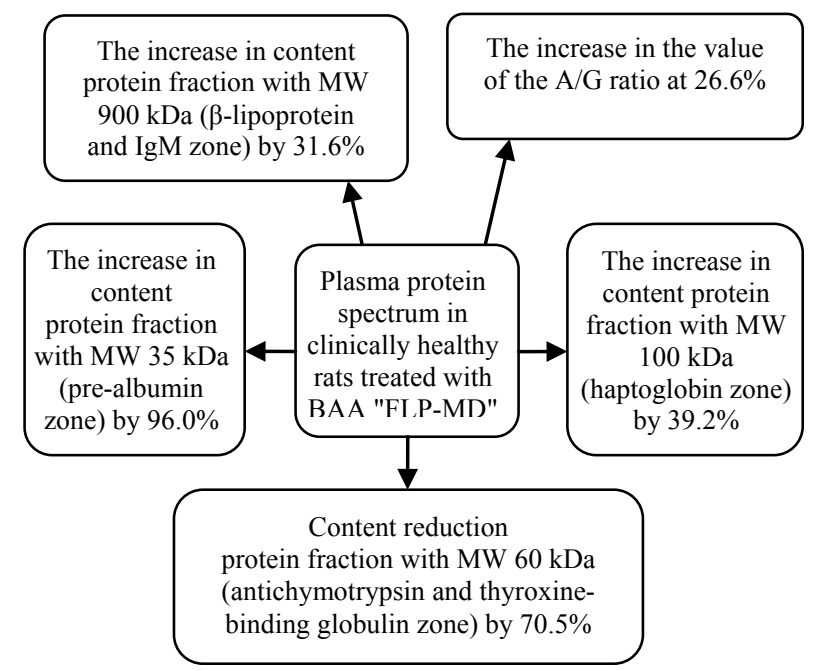

Fig. 3. The specific effect of BAA "FLP-MD" on the plasma protein spectrum of clinically healthy rats compared with intact animals

Similar patterns are observed with respect to changes in the relative number of the above protein fractions, in particular : increase in the relative level of proteins with molecular weights of $900 \mathrm{kDa}$ ( $\beta$-lipoprotein and IgM zone) by 1.3 times, $100 \mathrm{kDa}$ (haptoglobin zone) 1.4 times, 68 $70 \mathrm{kDa}$ (albumin zone) 1.1 times and $35 \mathrm{kDa}$ (pre-albumin zone) 
1.9 times and a decrease of $80 \mathrm{kDa}$ (transferrin zone) 1.2 times, $60 \mathrm{kDa}$ (antichymotrypsin and thyroxine-binding globulin zone) 3.5 times compared to the control. At the same time, there is an increase in the value of A/G ratio by $26.6 \%$ compared to control. However, the level of total protein remains within the control values with a slight upward trend.

The most sensitive indicators in terms of the degree of manifestation of the above absolute and relative quantitative changes in the blood plasma of clinically healthy animals which were administered BAA "FLPMD" include four protein fractions with molecular weights: $900 \mathrm{kDa}$ ( $\beta$-lipoprotein and IgM zone), $100 \mathrm{kDa}$ (haptoglobin zone), $35 \mathrm{kDa}$ (prealbumin zone) and $\mathrm{A} / \mathrm{G}$ ratio - are characterized by an increase in their quantitative parameters in the plasma of healthy animals and $60 \mathrm{kDa}$ (zone of antichymotrypsin and thyroxine-binding globulin), which is manifested by a corresponding decrease in its content compared to intact animals. Thus, this bioadditive has a specific effect on the proteinogram of blood plasma, even in clinically healthy animals.

Analysis of the results of the comparative evaluation of the plasma proteinogram of rats with toxic hepatitis in rats treated with $B A A$ " $F L P$ $M D$ " and clinically healthy animals receiving a similar bioadditive distinguishes three protein fractions and associated absolute and relative changes in quantitative characteristics (Fig. 4). Thus, in the blood plasma of sick animals receiving corrective therapy in the form of BAA "FLPMD" based on milk phospholipids, there was an increase in the absolute and relative content of the protein fraction with molecular weights: 180 $190 \mathrm{kDa}$ (IgE and IgD zone), respectively, by $36.4 \%$ and 1.4 times, and $72 \mathrm{kDa}$ (transferrin zone), respectively by $19.6 \%$ and 1.2 times, as well as a decrease in the absolute and relative content of the protein fraction with molecular weight $100 \mathrm{kDa}$ (haptoglobin zone), respectively by $55.1 \%$ and 2.2 times. The established patterns emphasize the active involvement in the biochemical and immunological processes of certain medium-molecular protein fractions, as the body's response to the development of hepatopathology and the use of corrective therapy.

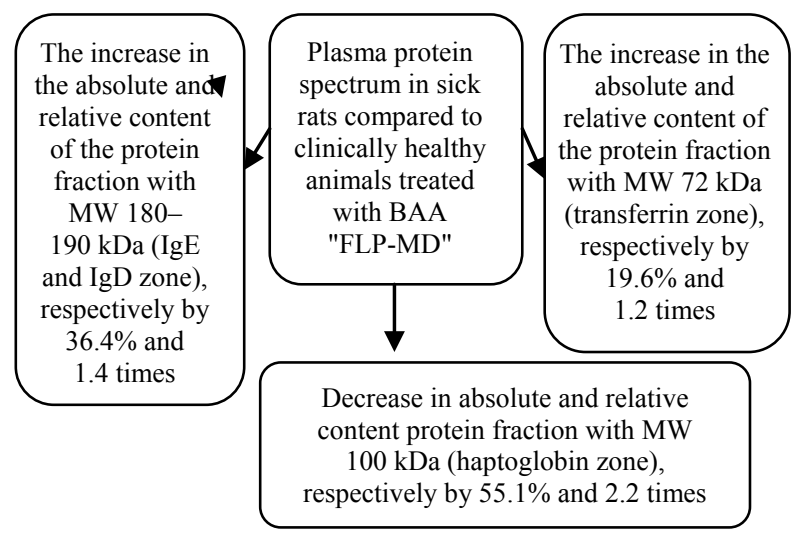

Fig. 4. Key changes in the absolute and relative content of protein fractions in the blood plasma of patients with toxic hepatitis in rats who received BAA "FLP-MD" in comparison with clinically healthy animals receiving a similar bioadditive

The study of the plasma protein spectrum of experimental rats identified the four most sensitive indicators that respond to the development of toxic diclofenac-induced hepatitis - protein fractions with molecular weights: $180-190,150-170,60$ and $54-58 \mathrm{kDa}$, and four markers of the effectiveness of recovery in such animals of protein-synthesizing liver function under the reparative action of BAA "FLP-MD" (according to the results of simultaneous testing on clinically healthy and sick rats), namely protein fractions with molecular weights: $900,180-190,68-70 \mathrm{kDa}$ and the value of the $\mathrm{A} / \mathrm{G}$ ratio, which is important for implementation in applied veterinary medicine. The established regularities are confirmed both in absolute, and in relative units of measurement.

\section{Conclusion}

The results of the analysis of the proteinogram of blood plasma of laboratory rats with experimental diclofenac-induced hepatitis using the method of vertical electrophoresis in polyacrylamide gel allowed us to establish the features of the pathogenesis of this hepatopathy at the molecular level. The determined regularities concerning quantitative changes of the total protein and individual fractions prove the presence of disorders of protein-synthesizing function of the liver in sick animals and the development of immunodeficiency. This is manifested by a probable decrease in blood plasma levels of both total protein and a decrease in the absolute and relative content of individual protein fractions. Among them it is worth noting four: with molecular weights of $180-190 \mathrm{kDa}$ (IgE and $\mathrm{IgD}$ zone), 150-170 kDa (IgA and IgG zone), $60 \mathrm{kDa}$ (pre-albumin zone) and 54 $58 \mathrm{kDa}$ (hemopexin and transcortin zone), which averages from $41.7 \%$ to $67.6 \%$ compared with intact animals. At the same time, the use of corrective therapy in the form of BAA "FLP-MD" based on milk phospholipids in animals with toxic hepatitis was accompanied by a specific increase in the quantitative characteristics of four indicators - protein fractions with molecular weights: $900 \mathrm{kDa}$ ( $\beta$-lipoprotein and IgM zone), $180-190 \mathrm{kDa}$ (IgE and $\mathrm{IgD}$ zone), $68-70 \mathrm{kDa}$ (albumin zone) and $\mathrm{A} / \mathrm{G}$ ratio on average by $20.3-33.9 \%$, which positively characterizes the corrective effectiveness of the applied therapy in relation to the protein-synthesizing function of the liver and immunobiological status of the organism. At the same time, quantitative changes of only one protein fraction $180-190 \mathrm{kDa}$ ( $\operatorname{IgE}$ and IgD zone) among the established marker indicators are sensitive both to the development of toxic hepatopathy and in determining the effectiveness of corrective therapy. The most sensitive experimentally established indicators of blood plasma proteinogram can be used in applied veterinary medicine as markers of development in animals of the drug form of toxic hepatitis, to determine the effectiveness of hepatoprotective therapy and to test the effectiveness of newly developed drugs.

\section{References}

Aithal, G. P., Watkins, P. B., Andrade, R. J., Larrey, D., Molokhia, M., Takikawa, H., Hunt, C. M., Wilke, R. A., Avigan, M., Kaplowitz, N., Bjornsson, E., \& Daly, A. K. (2011). Case definition and phenotype standardization in drug-induced liver injury. Clinical Pharmacology and Therapeutics, 89(6), 806-815.

Alberghina, D., Giannetto, C., Vazzana, I., Ferrantelli, V., \& Piccione, G. (2011). Reference intervals for total protein concentration, serum protein fractions, and albumin/globulin ratios in clinically healthy dairy cows. Journal of Veterinary Diagnostic Investigation, 23, 111-114.

Alempijevic, T., Zec, S., \& Milosavljevic, T. (2017). Drug-induced liver injury: Do we know everything? World Journal Hepatology, 9(10), 491-502.

Calitz, C., Hamman, J. H., Fey, S. J., Wrzesinski, K., \& Gouws, C. (2018). Recent advances in three-dimensional cell culturing to assess liver function and dysfunction: From a drug biotransformation and toxicity perspective. Toxicology Mechanisms and Methods, 28(5), 369-385.

Cong, L., Shuichi, S., \& Kousei, I., (2016). Assessment of mitochondrial dysfunction-related drug-induced hepatotoxicity in primary rat hepatocytes. Toxicology and Applied Pharmacology, 302(1), 23-30.

Didriksen, A., Grimnes, G., Hutchinson, M. S., Kjærgaard, M., Svartberg, J., Joakimsen, R. M., \& Jorde, R. (2013). The serum 25 -hydroxyvitamin D response to vitamin D supplementation is related to genetic factors, BMI, and baseline levels. European Journal of Endocrinology, 169(5), 559-567.

Eghtesad, S., Poustchi, H., \& Malekzadeh, R. (2013). Malnutrition in liver cirrhosis: The influence of protein and sodium. Middle East Journal of Digestive Diseases, 5(2), 65-75.

Forsthuber, M., Marius Kaiser, A., Granitzer, S., Hassl, I., Hengstschläger, M., Stangl, H., \& Gundacker, C. (2020). Albumin is the major carrier protein for PFOS, PFOA, PFHxS, PFNA and PFDA in human plasma. Environment International, 137, 105324 .

Gryshchenko, V. (2017). Biohimichnyj profil' plazmy krovi shhuriv za eksperymental'nogo gepatytu na tli vvedennja natriju dyklofenaku [Biochemical properties of the plasma of rats with the experimentally induced hepatitis after oral administration of sodium diclofenac]. Regulatory Mechanisms in Biosystems, 8(2), 191-196 (in Ukrainian).

Gryshchenko, V. A. (2017). Gematologichnyj profil' u shhuriv pry eksperymental'nomu dyklofenak-indukovanomu gepatyti [Hematological profile of rats in experimental diclofenac-induced hepatitis]. Ukrainian Journal of Ecology, 7(3), $78-83$ (in Ukrainian).

Gryshchenko, V. A. (2019). Zhovchno-kyslotnyj sklad krovi ta zhovchi v teljat za enteropatologiji ta zastosuvanni fosfolipidiv moloka [Blood and acid composition of blood and biles in calves with enteropathology and application of milk phospholipids]. Ukrainian Journal of Veterinary Sciences, 10(4), 36-42 (in Ukrainian).

Gryshchenko, V. A., Sysolyatin, S. V., \& Gulevata, J. V. (2018). Phospholipid composition of blood plasma and internal organs of rats with diclofenac-induced hepatitis. Ukrainian Journal of Ecology, 8(3), 235-240. 
Gutyi, B., Ostapiuk, A., Kachmar, N., Stadnytska, O., Sobolev, O., Binkevych, V., Petryshak, R., Petryshak, O., Kulyaba, O., Naumyuk, A., Nedashkivsky, V., Nedashkivska, N., Magrelo, N., Golodyuk, I., Nazaruk, N., \& Binkevych, O (2019). The effect of cadmium loading on protein synthesis function and functional state of laying hens' liver. Ukrainian Journal of Ecology, 9(3), 222-226.

Hu, Z. Y., Lausted, C., Yoo, H., Yan, X. W., Brightman, A., Chen, J. K., Wang, W.Z., Bu, X. L., \& Hood, L. (2014). Quantitative liver-specific protein fingerprint in blood: A signature for hepatotoxicity. Theranostics, 4(2), 215-228.

Jain, R. B., \& Ducatman, A. (2019). Perfluoroalkyl acids serum concentrations and their relationship to biomarkers of renal failure: Serum and urine albumin, creatinine, and albumin creatinine ratios across the spectrum of glomerular function among US adults. Environmental Research, 174, 143-151.

John, P., \& Kale, P. P. (2019). Prominence of oxidative stress in the management of anti-tuberculosis drugs related hepatotoxicity. Drug Metabolism Letters, 13(2), 95-101.

Kandemir, F. M., Yıldırım, S., Kucukler, S., Caglayan, C., Darendelioğlu, E., \& Dortbudak, M. B. (2020). Protective effects of morin against acrylamide-induced hepatotoxicity and nephrotoxicity: A multi-biomarker approach. Food and Chemical Toxicology, 138, 111190.

Kragh-Hansen, U., Chuang, V. T., \& Otagiri, M. (2002). Practical aspects of the ligand-binding and enzymatic properties of human serum albumin. Biological and Pharmaceutical Bulletin, 25(6), 695-704.

Kullak-Ublick, G. A., Andrade, R. J., Merz, M., End, P., Benesic, A., Gerbes, A. L., \& Aithal, G. P. (2017). Drug-induced liver injury: Recent advances in diagnosis and risk assessment. Recent Advances in Clinical Practice, 66(6), 1154-1164.

Kulyaba, O., Stybel, V., Gutyj, B., Turko, I., Peleno, R., Turko, Y., Golovach, P., Vishchur, V., Prijma, O., Mazur, I., Dutka, V., Todoriuk, V., Golub, O., Dmytriv, O., \& Oseredchuk, R. (2019). Effect of experimental fascioliasis on the protein synthesis function of cow liver. Ukrainian Journal of Ecology, 9(4), 612-615.

Laemmly, U. K. (1970). Cleavage of structural proteins during the assembly of the heat of Bacteriophage T4. Nature, 227(5259), 680-685.

Markley, J. L., \& Wencewicz, T. A. (2018). Tetracycline-inactivating enzymes. Frontiers in Microbiology, 9, 1058

Melnychuk, D. O., \& Gryshchenko, V. A. (2016). Sposib modelyuvannya toksichnogo gepatitu [Method of modeling of toxic hepatitis]. Patent UA, 105657, 2016 (in Ukrainian)

Melnychuk, D. O., Gryshchenko, V. A., \& Lytvynenko, O. N. (2009). Veterynarna biologichno aktyvna dobavka liposomal'noji formy ta sposib reparatyvnoji terapiji $\mathrm{v}$ gepatologiji [Veterinary biologically active additive of liposomal form and method of reparative therapy in hepatology]. Patent UA, 86516 (in Ukrainian).

Mengoli, M., Parmeggiani, D., Mengoli, M. C., Grinzi, G., \& Tolomelli, S. (2011). Drug-induced hepatotoxicity: Clinical and biochemical features of 26 patients and a review of the literature. Recenti Progressi in Medicina, 102(6), 253-260.
Nakano, K., Ando, H., Kurokawa, S., Hosohata, K., Ushijima, K., Takada, M., Tateishi, M., Yonezawa, A., Matsubara, K., Masuda, S., Inui, K., Morita, T., \& Fujimura, A. (2015). Association of decreased mRNA expression of multidrug and toxin extrusion protein 1 in peripheral blood cells with the development of flutamide-induced liver injury. Clinical Therapeutics, 37(8), e31.

Peter, J. S., \& Prince, S. E. (2018). Diclofenac-induced renal toxicity in female Wistar albino rats is protected by the pre-treatment of aqueous leaves extract of Madhuca longifolia through suppression of inflammation, oxidative stress and cytokine formation. Biomedicine and Pharmacotherapy, 98(12), 45-51.

Qin, S., Zhou, Y., Gray, L., Kusebauch, U., McEvoy, L., Antoine, D. J., Hampson, L., Park, K. B., Campbell, D., Caballero, J., Glusman, G., Yan, X., Kim, T.-K., Yuan, Y., Wang, K., Rowen, L., Moritz, R. L., Omenn, G. S., Pirmohamed, M., \& Hood, L. (2016). Identification of organ-enriched protein biomarkers of acute liver injury by targeted quantitative proteomics of blood in acetaminophen- and carbon-tetrachloride-treated mouse models and acetaminophen overdose patients. Journal of Proteome Research, 15(10), 3724-3740.

Quinlan, G. J., Martin, G. S., \& Evans, T. W. (2005). Albumin: Biochemical properties and therapeutic potential. Hepatology, 41(6), 1211-1219.

Rostom, A., Goldkind, L., \& Laine, L. (2005). Nonsteroidal anti-inflammatory drugs and hepatic toxicity: A systematic review of randomized concontrolled trils in arthritis patients. Clinical Gastroenterology and Hepatology, 3(5), 489-498.

Sanz-Villanueva, L., Parra-Martinez, C., Medina-Caliz, I., Sanabria-Cabrera, J., Robles-Diaz, M., Ortega-Alonso, A., Gonzalez-Jimenez, A., Gasca, J., Sanjuan-Jimenez, R., Garcia-Cortes, M., Lucena, M. I., \& Andrade, R. J. (2019). Accuracy of drug hepatotoxicity potential classifications in assessing severity related to drug-induced liver injury (DILI). European Journal of Clinical Pharmacology, 75(1), S103.

Schroeder, H. W., \& Cavacini, L. (2010). Structure and function of immunoglobulins. The Journal of Allergy and Clinical Immunology, 125(2), 41-52.

Schueller, F., Roy, S., Vucur, M., Trautwein, C., Luedde, T., \& Roderburg, C. (2018). The role of miRNAs in the pathophysiology of liver diseases and toxicity. International Journal of Molecular Sciences, 19(1), 261.

Singh, D., Qi, R., Jordan, J. L., San Mateo, L., \& Kao, C. C. (2013). The human antimicrobial peptide LL-37, but not the mouse ortholog, mCRAMP, can stimulate signaling by poly(I:C) through a FPRL1-dependent pathway. The Journal of Biological Chemistry, 288, 8258-8268.

Thakkar, S., Chen, M. J., Fang, H., Liu, Z. C., Roberts, R., \& Tong, W. D. (2018). The liver toxicity knowledge base (LKTB) and drug-induced liver injury (DILI) classification for assessment of human liver injury. Expert Review of Gastroenterology and Hepatology, 12(1), 31-38.

Van der Vusse, G. J. (2009). Albumin as fatty acid transporter. Drug Metabolism and Pharmacokinetics, 24(4), 300-307. 